\title{
Detection of quantitative trait loci for kernel oil and protein concentration in a B73 and Zheng58 maize cross
}

\author{
Z. Yang ${ }^{1,2}$, X. Li $^{4}$, N. Zhang ${ }^{4}$, Y.N. Zhang ${ }^{4}$, H.W. Jiang ${ }^{5}$, J. Gao ${ }^{4}$, \\ B.K. Kuai ${ }^{4}$, Y.L. Ding ${ }^{1,3}$, X.Q. Huang ${ }^{4}$ \\ ${ }^{1}$ The Southern Modern Forestry Collaborative Innovation Center, \\ Nanjing Forestry University, Nanjing, China \\ ${ }^{2}$ College of Biology and the Environment, Nanjing Forestry University, \\ Nanjing, China \\ ${ }^{3}$ Bamboo Research Institute, Nanjing Forestry University, Nanjing, China \\ ${ }^{4}$ State Key Laboratory of Genetic Engineering, School of Life Sciences, \\ Fudan University, Shanghai, China \\ ${ }^{5}$ College of Agriculture, Northeast Agricultural University, Harbin, China \\ Corresponding authors: Y.L. Ding / X.Q. Huang \\ E-mail: ylding@vip.163.com / xueqinghuang@fudan.edu.cn
}

Genet. Mol. Res. 15 (3): gmr.15038951

Received July 6, 2016

Accepted August 22, 2016

Published September 30, 2016

DOI http://dx.doi.org/10.4238/gmr.15038951

Copyright $(C 2016$ The Authors. This is an open-access article distributed under the terms of the Creative Commons Attribution ShareAlike (CC BY-SA) 4.0 License.

\begin{abstract}
Maize (Zea mays L.) is one of the most important food crops throughout the world, and provides oil and proteins to humans and livestock. Kernel oil and protein content in maize are two complex quantitative traits. In order to identify quantitative trait loci (QTL) controlling oil and protein concentration in maize kernels, and to evaluate their genetic effects, QTL analysis was conducted on an $\mathrm{F}_{3: 4}$ population derived from a cross between an inbred line with a low oil and protein concentration (Zheng58) and an inbred line with a higher
\end{abstract}


oil and protein concentration (B73). A total of 189 polymorphic simple sequence repeat markers were used to construct a linkage map. Eleven QTLs for kernel oil concentration were detected on nine chromosomes, except for chromosome 9. A single QTL explained 4.6 to $11.1 \%$ of the phenotypic variance. Ten QTLs for kernel protein concentration were also detected on nine chromosomes, except for chromosome 9. A single QTL explained 4.2 to $11.4 \%$ of the phenotypic variance. Interestingly, novel QTLs for oil concentration (qOIL08-01 and qOIL10-01) and QTLs for protein concentration ( $q$ PRO01-01 and $q P R O 05-01)$ were specific to the population studied, which could explain 7.1 to $11.1 \%$ of the phenotypic variance. These results will provide better understanding of the genetic basis of oil and protein concentrations in maize. The markers closely linked with the QTLs will facilitate breeding of maize varieties with high oil and protein concentrations through molecular marker-assisted selection.

Key words: QTL mapping; Maize; Kernel; Oil concentration; Protein concentration

\section{INTRODUCTION}

Maize is an important food, forage, and industrial raw material crop widely cultivated throughout the world (Yang et al., 2013). The global production of maize exceeds that of all other cereals (Ort and Long, 2014). Oil and protein are two important nutritional components of maize kernel. The maize kernel oil and protein contents varies from 4 to $5 \%$ and 8 to $10 \%$, respectively, in normal maize kernels (Zhang et al., 2008). Maize kernel oil contains fatty acids and unsaturated fatty acids, including palmitic, stearic, oleic, linoleic, and linolenic acids (Wassom et al., 2008). The main storage proteins in maize kernel are zeins (Wang et al., 2011), which are rich in amino acids. The relative levels of essential amino acids have been reported to be 3-14 mg/g (Flint-Garcia et al., 2009). The high protein and oil concentrations in maize kernels should be sufficient for human food, animal feed, and industrial processing (O'Quinn et al., 2000; Zhang et al., 2008). Thus, it is essential to breed high-quality varieties in order to improve the grain protein and oil content of normal maize. In general, kernel oil concentration is positively correlated with kernel protein concentration (Dudley and Lambert, 1992; Goldman et al., 1993). It is difficult to improve the concentration of different traits simultaneously in maize kernel in a fast and efficient manner using traditional breeding methods. Markers closely linked to kernel oil and protein content quantitative trait loci (QTLs) will help in the breeding of new varieties with high oil and protein concentrations through marker-assisted selection (MAS). Additionally, QTLs will aid our understanding of oil and protein synthesis and their genetic basis, and help to clone the oil and protein synthesis and accumulation genes by using map-based cloning strategies (Raihan et al., 2016).

The results of genetic studies have indicated that protein and oil concentrations in maize are complex traits controlled by both qualitative and quantitative genes. To date, nine genes corresponding to maize proteins have been cloned, including opaquel (ol) (Wang et al., 2012), o2 (Schmidt et al., 1990), o5 (Myers et al., 2011), o7 (Wang et al., 2011), flouryl (fl1) (Holding et al., 2007), fl2 (Coleman et al., 1997), fl4 (Wang et al., 2014), Mucronate

Genetics and Molecular Research 15 (3): gmr.15038951 
(Mc) (Kim et al., 2006), and Defective endosperm B30 (De-B30) (Kim et al., 2004). A few genes have been shown to influence maize kernel oil concentration, including linoleic acidl (ln1) (Poneleit and Alexander, 1965), Oleic acid content1 (olc1) (Wright, 1995), fatty acid desaturation 2 ( $f a d 2$ ), and fad6 (Poneleit and Alexander, 1965; Mikkilineni and Rocheford, 2003). Over the past two decades, genetic dissection of oil and protein concentrations in maize kernels by classical QTL mapping using biparental populations has resulted in the identification of numerous protein and oil QTLs. Yang et al. (2010) used a recombinant inbred population and identified a total of 58 QTLs for kernel oil concentration. Wassom et al. (2008) used 150 backcross 1-derived $\mathrm{S} 1\left(\mathrm{BC}_{1} \mathrm{~S}_{1}\right)$ lines to identify QTLs for the major fatty acids constituting oil from maize kernels, and mapped 18 QTLs for stearic, oleic, linoleic, and linolenic acids (Wassom et al., 2008). A study was initiated to detect QTLs controlling protein and starch concentration in maize; a total of 25 and 19 QTLs associated with protein and starch were detected, respectively (Goldman et al., 1993). Li et al. (2009) used two populations to evaluate kernel oil and starch concentrations under two environments, and detected four and one protein QTLs, respectively. However, no common QTL was shared between the two populations. Wang et al. (2010) used composite interval mapping and mapped 1-6 QTLs for grain oil and starch content in two populations under different environments. Wang et al. (2013) used a double haploid population and identified a total of 63 QTLs for oil content. Although large QTLs were detected in those studies, others have reported contrasting results, including QTL number, distribution, and genetic effect.

Therefore, in the present study, taking the complex and polygenic nature of kernel oil and protein concentration inheritance of maize into account, we developed a new $\mathrm{F}_{3: 4}$ mapping population generated from two contrasting parental lines for mapping kernel oil and protein concentration QTLs in the mature kernel state. We expect that further research into the genetic mechanism underlying the kernel oil and protein concentration trait could provide more favorable alleles for the genetic improvement of maize.

\section{MATERIAL AND METHODS}

\section{Field experiments and statistical analyses}

The $165 \mathrm{~F}_{3: 4}$ family lines were derived from crossing B73 with Zheng58. The parents of these populations were chosen on the basis of their different kernel phenotype. The Zheng58 kernels have an obvious opaque appearance at maturity, smooth, loosely packed starch granules, and an increased starchy region and decreased kernel hardness. The opaque endosperm phenotype is mostly associated with altered zeins accumulation at maturity. In the B73 kernels, which have a vitreous appearance, there is close contact between protein bodies and starch granules. The trials were performed at the experimental station located in Songjiang District, Shanghai, China during 2014 and 2015. A randomized complete block design with two replicates was applied. Each plot contained one row that was $3 \mathrm{~m}$ long and $0.67 \mathrm{~m}$ wide, with a total of 10 plants at a density of 50,000 plants/ha. Field management followed common agricultural practices of maize production in China.

Three strains of each line of the $\mathrm{F}_{3: 4}$ generation were selected at random and used to measure the oil and protein concentrations using approximately 200 kernels from each pollinated ear. The oil and protein concentration in kernel were measured by an FOSS NIRS DS2500 near-infrared analyzer ( $\mathrm{GmbH}$, Rellingen, Germany) as described previously (Liu et

Genetics and Molecular Research 15 (3): gmr.15038951 
al., 2013). Based on the means of the phenotypic data of the population, the SPSS11.5 software was used to perform descriptive statistics. For each trait, broad-sense heritability $\left(\mathrm{h}^{2}\right)$ was calculated for the variance between $\mathrm{F}_{3: 4}$ population (genotypic) and $\mathrm{F}_{3: 4}$ population by block (error) variance. Correlation coefficients between traits were obtained using the correlation analysis function in the SPSS software package.

\section{Genetic map construction and QTL mapping}

Young leaf samples were collected at the seedling stage from the $\mathrm{F}_{3}$ populations. Genomic DNA was extracted using the cetyltrimethylammonium ammonium bromide method (Saghai-Maroof et al., 1984). The DNA was quantified using a Colibri ultramicrospectrophotometer (Berthold Detection Systems, Germany) and subsequently stored at $-20^{\circ} \mathrm{C}$. Individuals from the $\mathrm{F}_{3}$ population were analyzed using simple sequence repeat (SSR) markers. In order to select the most informative SSR primer pairs, the parental lines, B73 and Zheng58, and an $\mathrm{F}_{1}$ individual, were screened with 211 SSR markers selected from the Maize Genetics and Genomic Database (MaizeGDB) based on their repeat unit and bin location. This resulted in the selection of 189 SSR primer pairs that were amplified using samples of the $\mathrm{F}_{3}$ individuals. Primer sequences are available from MaizeGDB.

PCR was run in a $10-\mu \mathrm{L}$ total volume with final concentrations of the following: 1 $\mu \mathrm{L}$ 10X PCR buffer, $0.2 \mu \mathrm{M}$ forward and reverse primers, $1.5 \mathrm{mM} \mathrm{MgCl}, 0.2 \mu \mathrm{M}$ dNTP, $0.1 \mathrm{U}$ Taq polymerase, and 50-100 ng template DNA, made up to $10 \mu \mathrm{L}$ with $\mathrm{ddH}_{2} \mathrm{O}$. The touchdown PCR cycling programs were as follows: $94^{\circ} \mathrm{C}$ for $3 \mathrm{~min}, 94^{\circ} \mathrm{C}$ for $30 \mathrm{~s}, 36$ cycles at $94^{\circ} \mathrm{C}$ for $30 \mathrm{~s}$, melting temperature $(\mathrm{Tm})$ for $30 \mathrm{~s}, 72^{\circ} \mathrm{C}$ for $30 \mathrm{~s}$, and in the first 16 cycles the annealing temperature was reduced by $1^{\circ} \mathrm{C}$ per cycle from 65 to $50^{\circ} \mathrm{C}$, the last 20 cycles were run at a constant $\mathrm{Tm} 50^{\circ} \mathrm{C}$, followed by $72^{\circ} \mathrm{C}$ for $10 \mathrm{~min}$.

Linkage groups were assigned to the corresponding chromosome using the SSR map locations from the consensus maize map as shown in the MaizeGDB. The software package MapQTL 5.0 was used to identify and locate QTLs on the linkage map through interval mapping and multiple-QTL model (MQM) mapping methods as described in the instruction manual (http://www.kyazma.nl). In the first step, putative QTLs were identified using interval mapping. Thereafter, the closest marker to each putative QTL was selected as a cofactor (Churchill and Doerge, 1994) and the selected markers were used as genetic background controls in the approximate multiple QTL model of MapQTL. The $\log 10$ of the odds ratio (LOD) threshold values applied to declare the presence of QTLs, were estimated by performing permutation tests implemented in MapQTL version 5.0 using at least 1000 permutations of the original data set, resulting in a 95\% LOD threshold of 2.9. The estimated additive genetic effect, the percentage variance explained by each QTL, and the total variance explained by all QTLs affecting a trait were obtained using MQM mapping.

\section{RESULTS}

\section{Analysis of the oil and protein concentration of B73 and Zheng58 kernels in the $F_{3: 4}$ population and parental lines}

The kernels of B73 and Zheng58 used in this study showed a different phenotype on the white light box (Figure 1). A positive correlation has been reported between zein proteins

Genetics and Molecular Research 15 (3): gmr.15038951 
and kernel vitreousness (Moose et al., 2004). Therefore, quantitative or qualitative reductions in the levels of zein proteins may result in starchy or opaque endosperm phenotypes. The oil concentration of B73 and Zheng58 kernels was $4.92 \%$ and $4.10 \%$, respectively; and the protein concentration was 12.94 and $11.46 \%$, respectively (Table 1). From the $\mathrm{F}_{2}$ progeny, single-seed descent was applied to produce 165 lines at the $\mathrm{F}_{4}$ generation. Table 1 presents descriptive statistics of the kernel protein and oil concentration for the two parents and the $\mathrm{F}_{3: 4}$ population. Large differences were found for these traits between the two parents, and the wider range of variation for the traits in the $\mathrm{F}_{3: 4}$ population and normal distributions with transgressive segregation, suggested polygenic inheritance of the traits (Figure 2). In addition, there was a strong correlation between the oil and protein concentrations, and the estimated $\mathrm{h}^{2}$ values for traits was generally high and ranged from 0.78 to 0.84 . (Table 1 ).
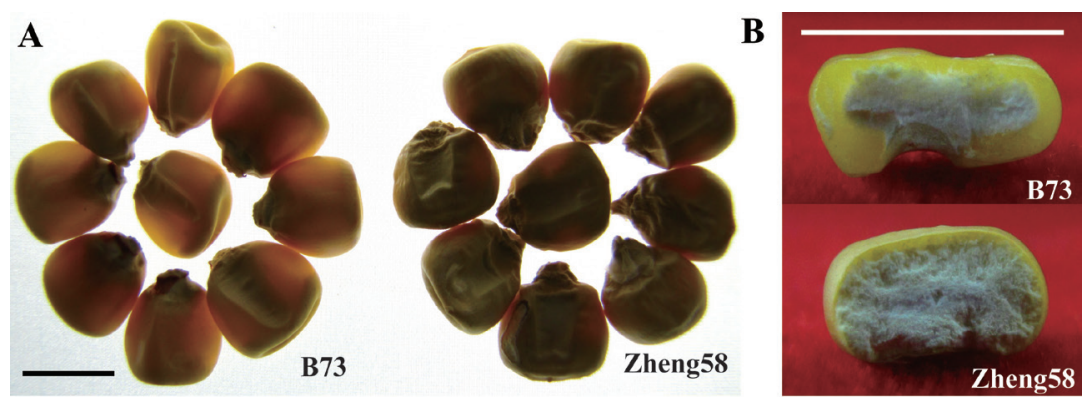

Figure 1. Light transmission by mature B73 and Zheng58 kernels. A. Kernels of the inbred lines B73 and Zheng58 were randomly selected and viewed on a light box. Bars $=1 \mathrm{~cm}$. B. Transverse section of a B73 (top) and Zheng58 kernel (bottom).

Table 1. Descriptive statistics of the oil and protein concentration in parental lines (B73 and Zheng58) and the population of $\mathrm{F}_{3: 4}$ at seed maturity stage.

\begin{tabular}{|c|c|c|c|c|c|c|c|c|c|}
\hline \multirow[t]{2}{*}{ Trait $^{\mathrm{a}}$} & \multirow[t]{2}{*}{$\mathrm{B} 73^{\mathrm{b}}(\%)$} & \multirow[t]{2}{*}{ Zheng58 $8^{\mathrm{b}}(\%)$} & \multicolumn{7}{|c|}{$\mathrm{F}_{3: 4}$ population } \\
\hline & & & $\operatorname{Max}(\%)$ & $\operatorname{Min}(\%)$ & Mean (\%) & SD & Kurtosis & Skewness & $\mathrm{h}^{2 \mathrm{c}}$ \\
\hline Oil & 4.92 & 4.10 & 6.04 & 3.31 & 4.57 & 0.485 & -0.007 & 0.049 & 0.78 \\
\hline Protein & 12.94 & 11.46 & 9.65 & 15.56 & 12.91 & 1.13 & 0.073 & -0.192 & 0.84 \\
\hline
\end{tabular}

${ }^{\mathrm{a}} \mathrm{Oil}$ represents the kernel oil concentration, protein represents the kernel protein concentration. ${ }^{\mathrm{b}} \mathrm{The}$ numbers in each cell represent the mean value for the parent. All differences between the parents are statistically significant at the 0.01 probability level. ${ }^{~}$ Heritability (\%) calculated as described in Material and Methods.

\section{Linkage maps of $\mathbf{F}_{3: 4}$ populations}

A survey of 393 SSR primer pairs identified 207 polymorphic loci between the parents. According to the physical position of the SSR markers obtained from the results of genome sequencing of $\mathrm{B} 73$, a total of 189 informative SSR markers were used to genotype the $\mathrm{F}_{3: 4}$ population from B73 x Zheng58. The number of markers placed in different chromosomes ranged from 13 to 29 , with an average number of 18.9. The greatest distance between markers was $38.98 \mathrm{Mb}$, and the shortest was $1.41 \mathrm{Mb}$. The average genetic distance was $10.89 \mathrm{Mb}$ between two neighboring markers and the distribution of markers in all chromosomes was relatively even without crowding (Figure 3). 

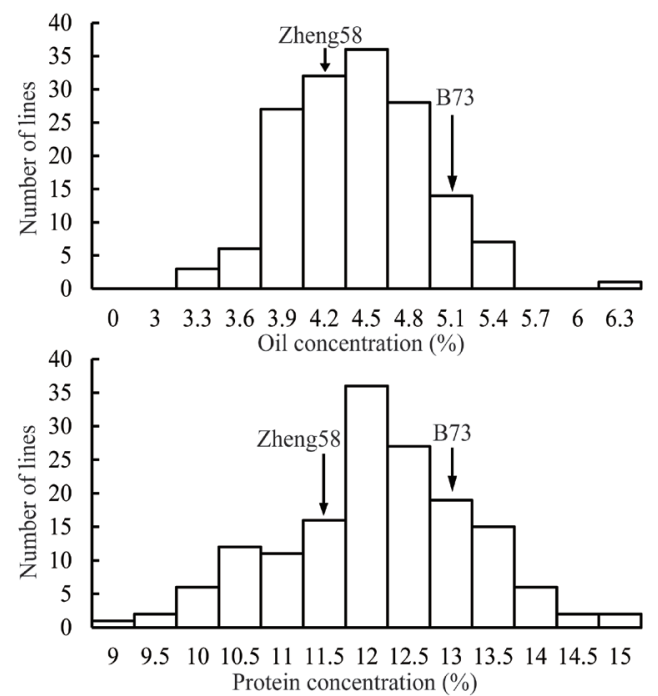

Figure 2. Frequency distribution of the oil and protein concentration in the $\mathrm{F}_{3: 4}$ population of B73 x Zheng58. Arrows indicate the average values for Zheng58 (lower oil and protein concentration) and B73 (higher oil and protein concentration)

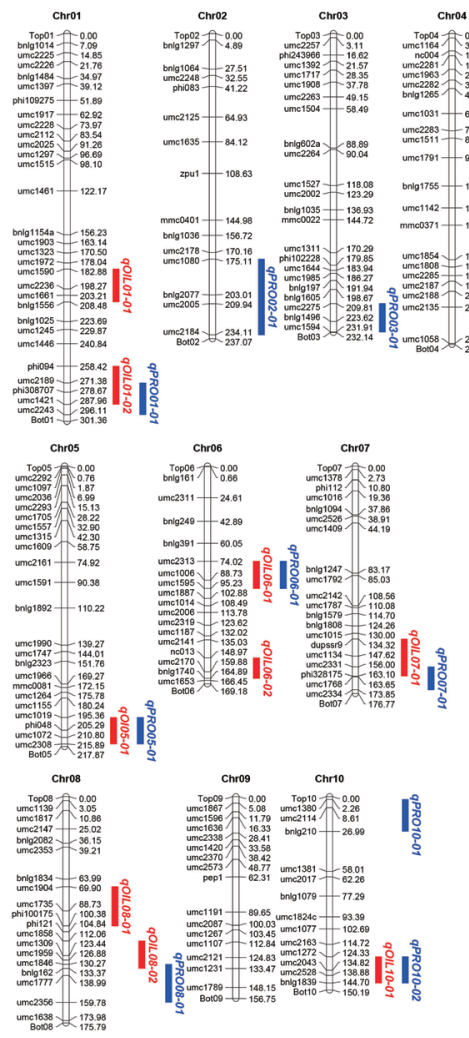

Figure 3. Genetic linkage map and distribution of major quantitative trait loci for oil and protein concentration.

Genetics and Molecular Research 15 (3): gmr.15038951 


\section{Identification of kernel protein and oil concentration QTLs}

QTLs for kernel protein and oil concentration were analyzed using the MAPQTL5.0 software and 21 QTLs were detected (Figure 3 and Table 2). Among them, three QTLs were detected on chromosome 1 (qPRO01-01, qOIL01-01, qOIL01-02), three QTLs were detected on chromosome 4 (qPRO04-01, qOIL04-01, qOIL04-02), two QTLs were detected on chromosome 5 ( $q$ PRO05-01, qOIL05-01), three QTLs were detected on chromosome 6 (qPRO06-01, qOIL06-01, qOIL06-02), three QTLs were detected on chromosome 7 (qPRO01-01, qOIL07-01, qOIL07-02), three QTLs were detected on chromosome 8 (qPRO08-01, qOIL08-01, qOIL08-02), three QTLs were detected on chromosome 10 (qPRO10-01, qOIL10-02, qOIL10-01), and one QTL was detected each on chromosomes 2 (qPRO02-01) and 3 (qPRO03-01). Some QTLs detected for different traits were found located within the same interval. For example, two QTLs were located on chromosome 1 (umc2189umc1421 interval), two QTLs on chromosome 5 (umc1019-umc2308 interval), two QTLs on chromosome 6 (umc2313-umc1595 interval), and two QTLs on chromosome 10 (umc1272bnlg1839 interval). It is notable that all QTLs had positive additive effects, with the exception of qPRO10-01, indicating that B73 contributed alleles for oil and protein concentration s. Eleven QTLs on chromosomes 1, 4, 5, 6, 7, 8, and 10, were identified for oil concentration (Figure 3 and Table 2), which explained $82 \%$ of the total phenotypic variance. A single QTL accounted for 4.6 to $11.1 \%$ of the phenotypic variance. Ten QTLs for protein concentration, accounting for $72.8 \%$ of the total phenotypic variance, were identified on chromosomes 1 , 2, 3, 4, 5, 6, 7, 8, and 10 (Figure 3 and Table 2). A single QTL explained 4.2 to $11.4 \%$ of the phenotypic variance.

Table 2. QTL analysis of maize kernel oil and protein concentration in the $\mathrm{F}_{3: 4}$ population of B73 x Zheng58.

\begin{tabular}{|c|c|c|c|c|c|c|c|c|}
\hline Trait $^{\mathrm{a}}$ & QTL & $\mathrm{Chr}^{\mathrm{b}}$ & Position (Mb) & Marker interval $^{\mathrm{c}}$ & Closest markers to QTL & LOD $^{d}$ & Additive effect & Explained variance (\%) \\
\hline \multirow[t]{11}{*}{ Oil } & qOIL01-01 & 1 & 296.25 & umc1590-bnlg1556 & umc2236 & 3.46 & 0.183 & 4.6 \\
\hline & qOIL01-02 & 1 & 273.51 & phi094-umc1421 & umc2189 & 5.27 & 0.258 & 8.6 \\
\hline & \begin{tabular}{|l|} 
qOIL04-01 \\
\end{tabular} & 4 & 13.41 & umc1164-umc2281 & nc004 & 4.46 & 0.223 & 7 \\
\hline & qOIL04-02 & 4 & 169.26 & umc0371-umc2187 & umc1854 & 3.6 & 0.189 & 5.2 \\
\hline & qOIL05-01 & 5 & 210.8 & umc1019-umc2038 & umc1072 & 5.1 & 0.251 & 8.1 \\
\hline & qOIL06-01 & 6 & 86.23 & umc2313-umc1595 & umc1006 & 5.9 & 0.284 & 10.2 \\
\hline & qOIL06-02 & 6 & 157.78 & nc013-bnlg1740 & umc2170 & 4.22 & 0.214 & 6.4 \\
\hline & qOIL07-01 & 7 & 149.21 & dupssr9- phi328175 & umc1134 & 4.1 & 0.206 & 6.2 \\
\hline & qOIL08-01 & 8 & 85.63 & umc1904-phi100175 & umc1735 & 6.57 & 0.302 & 11.1 \\
\hline & qOIL08-02 & 8 & 125.68 & umc1858-bnlg162 & umc1959 & 4.62 & 0.232 & 7.2 \\
\hline & qOIL10-01 & 10 & 134.82 & umc1272- bnlg1839 & umc2043 & 4.72 & 0.237 & 7.4 \\
\hline \multirow[t]{10}{*}{ Protein } & qPRO01-01 & 1 & 285.47 & umc219-umc2243 & umc1421 & 4.55 & 0.593 & 7.1 \\
\hline & qPRO02-01 & 2 & 205.21 & umc1080-umc2184 & bnlg2077 & 6.63 & 0.794 & 11.4 \\
\hline & qPRO03-01 & 3 & 221.48 & umc2275-umc1594 & bnlg1496 & 4.06 & 0.538 & 6.1 \\
\hline & qPRO04-01 & 4 & 240.6 & umc2135-umc 1058 & umc 1058 & 3.19 & 0.465 & 4.2 \\
\hline & qPRO05-01 & 5 & 210.8 & umc1019-umc2038 & umc1072 & 4.63 & 0.601 & 7.2 \\
\hline & qPRO06-01 & 6 & 86.23 & umc2313-umc1595 & umc1006 & 6.25 & 0.756 & 10.5 \\
\hline & qPRO07-01 & 7 & 164.25 & umc2331-umc2334 & umc1768 & 5.29 & 0.657 & 8.6 \\
\hline & qPRO08-01 & 8 & 144.36 & umc1846-umc2356 & umc1777 & 3.94 & 0.527 & 5.5 \\
\hline & qPRO10-01 & 10 & 5.88 & umc1380-bnlg210 & umc2114 & 4.38 & -0.653 & 6.8 \\
\hline & qPRO10-02 & 10 & 136.98 & umc1272- bnlg1839 & umc2528 & 3.82 & 0.515 & 5.4 \\
\hline
\end{tabular}

${ }^{\mathrm{a}} \mathrm{QTL}$ names are indicated as $q O I L$ (QTL for kernel oil concentration) and $q P R O$ (QTL for kernel protein concentration) followed by a number (chromosome number) and a word (for more than one QTL on the same chromosome). ${ }^{b} \mathrm{Chr}$ (Chromosome). ${ }^{\mathrm{c}}$ Markers within the QTL region that flank the peak of the LOD scan. ${ }^{\mathrm{d}} \mathrm{LOD}$ ( $\log 10$ of the odds ratio).

Genetics and Molecular Research 15 (3): gmr.15038951 


\section{DISCUSSION}

The kernel protein and oil concentration trait of maize is generally regulated by complex factors. Identification of QTLs is a useful approach to elucidate the molecular basis of this trait. In the past few decades, a wealth of QTL mapping data for the kernel protein and oil concentration in maize has been obtained using molecular marker approaches. Zhang et al. (2008) identified six QTLs for oil concentration on chromosomes 1, 2, 4, 6, and 8, and six QTLs for protein concentration on chromosomes 1, 2, 6, 7, 8, and 9. Among the six oil concentration QTLs, the oilc4-1 and oilc4-2 were located near to the qOIL04-01 detected in our study. Wang et al. (2010) used two $\mathrm{F}_{3: 4}$ families developed from two crosses between one high-oil inbred maize line and two normal inbred maize lines. A total of 21 QTLs for oil content were detected mainly on chromosome 6. In our study, qOIL06-1 and qPRO061 were also detected in the same region of chromosome 6 . Meanwhile, the nearest marker, umc1006, of $q$ OIL06-1 and qPRO06-1 was also the linkage marker of QTL for stearic acid (Wassom et al., 2008). Zhang et al. (2015) detected a total 25 and 13 QTLs for protein and oil content using a recombinant inbred population in different environments. qOIL05-01 and qOIL08-02 detected in the present study, were found in the same regions as q3Bo5-1, 3Bo71 , and $q 3 B o 8-1$ on chromosomes 5, 7, and 8. qPRO02-01 and $q P R O 03-01$ were on the same regions as $q 2 B p 2-2$ and $q 2 X p 3-2$ on chromosomes 2 and 3. The consistent and stable QTLs detected in different genetic backgrounds indicate that these chromosome regions are crucial in the control of oil and protein concentration, and can be used for QTL fine mapping or for the identification of candidate genes in future studies. In addition, in this study, two QTLs for oil concentration were detected on chromosomes 8 and 10, including qOIL08-01 and qOIL1001 . In addition, two QTLs for protein concentration were detected on chromosomes 1 and 5, including $q P R O 01-01$ and $q P R O 05-01$, which have not previously been reported in maize, demonstrating that the QTLs had a population-specific effect and were strongly influenced by different genetic backgrounds (Dudley et al., 2004; Yang et al., 2014). Therefore, the new QTLs detected in this study supplement the QTLs reported for kernel oil and protein concentration in previous reports.

Zeins are the the main storage proteins in endosperm maize kernel (Wang et al., 2011). A positive correlation has been reported between zein proteins and kernel vitreousness (Moose et al., 2004). Therefore, either quantitative or qualitative reductions in the levels of zein proteins may result in starchy or opaque endosperm phenotypes. There are 18 mutants that can exhibit an opaque or floury endosperm. Nine genes corresponding to maize proteins have been cloned, including o1 (Wang et al., 2012), o2 (Schmidt et al., 1990), o5 (Myers et al., 2011), o7 (Wang et al., 2011), fll (Holding et al., 2007), fl2 (Coleman et al., 1997), fl4 (Wang et al., 2014), Mc (Kim et al., 2006), and De-B30 (Kim et al., 2004). In the present study, qPRO04-01 was detected in the region of the $o 2$ locus on chromosome 4, and qPRO10-02 was detected in the region of the $f 4$ locus on chromosome 10. 02 and $f l 4$ were most likely to be responsible for $q P R O 04-01$ and $q P R O 10-02$, respectively. Only a few genes related to maize kernel oil have been reported, including $\ln 1$ (Poneleit and Alexander, 1965), olc1 (Wright, 1995), fad2 and fad6 (Poneleit and Alexander, 1965; Mikkilineni and Rocheford, 2003). In our study, $q O I L-06-01$ was detected in the region of the $\ln 1$ locus on chromosome $6 . \ln 1$ was most likely to be responsible for qOIL-06-01. Oil and protein are important components of maize kernels. In general, oil concentration is positively correlated with protein concentration (Dudley and Lambert, 1992; Goldman et al., 1993). The positive correlation between protein

Genetics and Molecular Research 15 (3): gmr.15038951 
and oil content implies that it is possible to increase oil and protein content simultaneously (Champoux et al., 1995; Zhang et al., 2015). Our mapping result also showed there was a high correlation between oil and protein concentration. The genetic basis of such a high correlation can largely be explained by the co-localization of QTLs for the two traits, either due to pleiotropic effects or tight linkage. Examples of such genomic regions included: the interval marked by umc 2189 and umc1421 on chromosome 1, umc1019 and umc2308 on chromosome 5 , umc2313 and umc1595 on chromosome 6, umc2331 and phi328175 on chromosome 7, and umc1272 and bnlg1839 on chromosome 10. These data suggest that maize kernel oil and protein concentration may be an excellent combined indicator of the two traits.

The main purpose of mapping kernel oil and protein concentration QTLs is to perform MAS and to introduce high oil and protein QTL alleles to high-yield lines with low oil and protein concentrations. In this study, 21 QTLs for oil and protein concentration were detected. Further experiments are underway to validate QTL effects using heterogeneous inbred families, which will help maize breeders to accumulate desirable allelic combinations and help to develop functional markers to fine-map and clone functional genes in future investigations.

\section{Conflicts of interest}

The authors declare no conflict of interest.

\section{ACKNOWLEDGMENTS}

Research supported by the Shanghai Pujiang Program (\#14PJ1400700), the National Program of Transgenic Variety Development of China (\#2016ZX08003004-009), and the Project Funded by the Priority Academic Program Development of Jiangsu Higher Education Institutions (PAPD).

\section{REFERENCES}

Champoux MC, Wang G, Sarkarung S, Mackill DJ, et al. (1995). Locating genes associated with root morphology and drought avoidance in rice via linkage to molecular markers. Theor. Appl. Genet. 90: 969-981. http://dx.doi. org/10.1007/BF00222910

Churchill GA and Doerge RW (1994). Empirical threshold values for quantitative trait mapping. Genetics 138: 963-971.

Coleman CE, Clore AM, Ranch JP, Higgins R, et al. (1997). Expression of a mutant alpha-zein creates the floury2 phenotype in transgenic maize. Proc. Natl. Acad. Sci. USA 94: 7094-7097. http://dx.doi.org/10.1073/pnas.94.13.7094

Dudley JW and Lambert RJ (1992). Ninety generations of selection for oil and protein in maize. Maydica 37: 81-87.

Dudley JW, Dijkhuizen A, Paul C, Coates ST, et al. (2004). Effects of random mating on marker-QTL associations in the cross of the Illinois high protein X Illinois low protein maize strains. Crop Sci. 44: 1419-1428. http://dx.doi. org/10.2135/cropsci2004.1419

Flint-Garcia SA, Guill KE, Sanchez-Villeda H, Schroeder SG, et al. (2009). Maize amino acid pathways maintain high levels of genetic diversity. Maydica 54: 375-386.

Goldman IL, Rocheford TR and Dudley JW (1993). Quantitative trait loci influencing protein and starch concentration in the Illinois Long Term Selection maize strains. Theor. Appl. Genet. 87: 217-224. http://dx.doi.org/10.1007/ BF00223767

Holding DR, Otegui MS, Li B, Meeley RB, et al. (2007). The maize floury1 gene encodes a novel endoplasmic reticulum protein involved in zein protein body formation. Plant Cell 19: 2569-2582.

Kim CS, Hunter BG, Kraft J, Boston RS, et al. (2004). A defective signal peptide in a 19-kD alpha-zein protein causes the unfolded protein response and an opaque endosperm phenotype in the maize De*-B30 mutant. Plant Physiol. 134: 380-387.

Genetics and Molecular Research 15 (3): gmr.15038951 
Kim CS, Gibbon BC, Gillikin JW, Larkins BA, et al. (2006). The maize Mucronate mutation is a deletion in the 16-kDa gamma-zein gene that induces the unfolded protein response. Plant J. 48: 440-451. http://dx.doi.org/10.1111/j.1365313X.2006.02884.X

Li Y, Wang Y, Wei M, Li X, et al. (2009). QTL identification of grain protein concentration and its genetic correlation with starch concentration and grain weight using two populations in maize (Zea mays L.). J. Genet. 88: 61-67. http:// dx.doi.org/10.1007/s12041-009-0008-z

Liu L, Qu C, Wittkop B, Yi B, et al. (2013). A high-density SNP map for accurate mapping of seed fibre QTL in Brassica napus L. PLoS One 8: e83052. http://dx.doi.org/10.1371/journal.pone.0083052

Mikkilineni V and Rocheford TR (2003). Sequence variation and genomic organization of fatty acid desaturase-2 (fad2) and fatty acid desaturase-6 (fad6) cDNAs in maize. Theor. Appl. Genet. 106: 1326-1332.

Moose SP, Dudley JW and Rocheford TR (2004). Maize selection passes the century mark: a unique resource for 21st century genomics. Trends Plant Sci. 9: 358-364. http://dx.doi.org/10.1016/j.tplants.2004.05.005

Myers AM, James MG, Lin Q, Yi G, et al. (2011). Maize opaque5 encodes monogalactosyldiacylglycerol synthase and specifically affects galactolipids necessary for amyloplast and chloroplast function. Plant Cell 23: 2331-2347. http:// dx.doi.org/10.1105/tpc.111.087205

O'Quinn PR, Nelssen JL, Goodband RD, Knabe DA, et al. (2000). Nutritional value of a genetically improved high-lysine, high-oil corn for young pigs. J. Anim. Sci. 78: 2144-2149. http://dx.doi.org/10.2527/2000.7882144x

Ort DR and Long SP (2014). Limits on yields in the corn belt. Science 344: 484-485. http://dx.doi.org/10.1126/ science. 1253884

Poneleit CG and Alexander DE (1965). Inheritance of linoleic and oleic acids in maize. Science 147: 1585-1586. http:// dx.doi.org/10.1126/science.147.3665.1585

Raihan MS, Liu J, Huang J, Guo H, et al. (2016). Multi-environment QTL analysis of grain morphology traits and fine mapping of a kernel-width QTL in Zheng58 x SK maize population. Theor. Appl. Genet. 129: 1465-1477. http:// dx.doi.org/10.1007/s00122-016-2717-Z

Saghai-Maroof MA, Soliman KM, Jorgensen RA and Allard RW (1984). Ribosomal DNA spacer-length polymorphisms in barley: mendelian inheritance, chromosomal location, and population dynamics. Proc. Natl. Acad. Sci. USA 81: 8014-8018. http://dx.doi.org/10.1073/pnas.81.24.8014

Schmidt RJ, Burr FA, Aukerman MJ and Burr B (1990). Maize regulatory gene opaque-2 encodes a protein with a "leucine-zipper" motif that binds to zein DNA. Proc. Natl. Acad. Sci. U. S. A. 87: 46-50.

Wang G, Sun X, Wang G, Wang F, et al. (2011). Opaque7 encodes an acyl-activating enzyme-like protein that affects storage protein synthesis in maize endosperm. Genetics 189: 1281-1295.

Wang G, Wang F, Wang G, Wang F, et al. (2012). Opaque1 encodes a myosin XI motor protein that is required for endoplasmic reticulum motility and protein body formation in maize endosperm. Plant Cell 24: 3447-3462. http:// dx.doi.org/10.1105/tpc. 112.101360

Wang G, Qi W, Wu Q, Yao D, et al. (2014). Identification and characterization of maize floury4 as a novel semi-dominant opaque mutant that disrupts protein body assembly. Plant Physiol. 165: 582-594. http://dx.doi.org/10.1104/ pp. 114.238030

Wang X, Wang H, Long Y, Li D, et al. (2013). Identification of QTLs associated with oil content in a high-oil Brassica napus cultivar and construction of a high-density consensus map for QTLs comparison in B. napus. PLoS One 8: e80569. http://dx.doi.org/10.1371/journal.pone.0080569

Wang YZ, Li JZ, Li YL, Wei MG, et al. (2010). QTL detection for grain oil and starch content and their associations in two connected F-2:3 populations in high-oil maize. Euphytica 174: 239-252. http://dx.doi.org/10.1007/s10681-010$\underline{0123-1}$

Wassom JJ, Mikkelinem V, Bohn MO and Rocheford TR (2008). QTL for fatty acid composition of maize kernel oil in Illinois high oil x B73 backcross-derived lines. Crop Sci. 48: 69-78. http://dx.doi.org/10.2135/cropsci2007.04.0208

Wright A (1995). A gene conditioning high oleic maize oil, Olc1. Maydica 40: 85-88.

Yang G, Dong Y, Li Y, Wang Q, et al. (2013). Verification of QTL for grain starch content and its genetic correlation with oil content using two connected RIL populations in high-oil maize. PLoS One 8: e53770. http://dx.doi.org/10.1371/ journal.pone. 0053770

Yang GH, Dong YB, Li YL, Wang QL, et al. (2014). QTL verification of grain protein content and its correlation with oil content by using connected RIL populations of high-oil maize. Genet. Mol. Res. 13: 881-894. http://dx.doi. org/10.4238/2014.February.14.18

Yang X, Guo Y, Yan J, Zhang J, et al. (2010). Major and minor QTL and epistasis contribute to fatty acid compositions and oil concentration in high-oil maize. Theor. Appl. Genet. 120: 665-678. http://dx.doi.org/10.1007/s00122-009-1184-1

Zhang HD, Jin TT, Huang YQ, Chen JT, et al. (2015). Identification of quantitative trait loci underlying the protein, oil and starch contents of maize in multiple environments. Euphytica 205: 169-183. http://dx.doi.org/10.1007/s10681$\underline{015-1419-\mathrm{y}}$

Zhang J, Lu XQ, Song XF, Yan JB, et al. (2008). Mapping quantitative trait loci for oil, starch, and protein concentrations in grain with high-oil maize by SSR markers. Euphytica 162: 335-344. http://dx.doi.org/10.1007/s10681-007-9500-9

Genetics and Molecular Research 15 (3): gmr.15038951 